\title{
RELATION OF CHRONOLOGY OF DECIDUOUS TOOTH EMERGENCE TO HEIGHT, WEIGHT AND HEAD CIRCUMFERENCE IN CHILDREN
}

\author{
P. F. INFANTE* and G. M. OWEN $\dagger$ \\ * Programme in Oral Epidemiology, School of Public Health, The University of \\ Michigan, Ann Arbor, Michigan 48104, U.S.A., † Department of Pediatrics, Ohio \\ State University, The Children's Hospital Research Foundation, Columbus, Ohio \\ 43205, U.S.A.

\begin{abstract}
Summary -In this United States probability sample of a nutritional survey conducted in 1969-1970, data for 273 caucasoid children (ages 1-3 yr) were analysed to determine if deciduous tooth emergence was related to height, weight and head circumference. The coefficient of association, $Q$, was positive for all comparisons. Chi-square analyses demonstrated significant associations between the total number of teeth present and height, weight and head circumference in boys; the associations in girls were significant for teeth vs height. These findings indicate that the timing of deciduous tooth emergence is significantly related to general somatic growth and perhaps nutritional status.
\end{abstract}

\section{INTRODUCTION}

THE relation of deciduous tooth emergence to a child's growth and development has been little studied. The sparse literature on this subject usually states that deciduous tooth emergence is relatively independent of other growth processes. Most reports, however, are based on limited subject numbers or inadequately described methods and the older studies lack adequate statistical analysis with contradictory and confusing results.

FALKNER (1957) concluded that smaller children erupt teeth earlier than children of average stature and that sick, hospitalized children erupt teeth later than the average child. BOAS (1927), found that smaller children were retarded in deciduous tooth emergence but did not publish statistical analysis to demonstrate the significance of differences observed. Others have concluded that there is no association between deciduous tooth emergence and stature (RoBINOw, RiCHARDS and ANDERSON, 1942; LySELl, MAGNUSSEN and THILANDER, 1962), though inspection of their data suggests positive association. SANDLER (1944) found no relation between the number of teeth present and weight in a combined group of boys and girls. WeDGEWOoD and HoLT (1968) were unable to demonstrate any association between tooth emergence and height, weight and skeletal maturity by a follow-up examination of children who weighed $2500 \mathrm{~g}$ or less at birth. Most of the children recalled in the study, however, were at least $3 \mathrm{yr}$ of age and too old for even late deciduous tooth emergence to be observed. Meredith (1946) presented data from MAY and WYGANT (1939) which, upon statistical analysis, show normal full-term infants to be significantly advanced in relation to premature (low birth weight) infants in the commencement of deciduous 
tooth emergence. Ferguson, ScotT and BAKwIN (1957) reported lower class American negro children to be significantly retarded in tooth emergence when compared to middle class negro children, but equal in tooth emergence when compared to middle class caucasoid children. In view of the confusing results of these reports, an investigation was undertaken to determine the relation of deciduous tooth emergence to a child's growth as manifested by measurements of height, weight and head circumference.

\section{MATERIALS AND METHODS}

A study of the nutritional status of pre-school children of the United States was conducted in 1969-1970. Seventy-four sampling areas were chosen to represent a national sample (Kish and Hess, 1965). Dental examinations were carried out on $60-80$ per cent of the children included in the primary sampling units in all regions of the country except the North Central where one-third were examined. Therefore data on subjects were not based on a strict probability selection, and inferences may not be made equally for all parts of the country. Dental data represented subjects from metropolitan areas such as Boston, Philadelphia, Chicago, Miami, Los Angeles, San Francisco, Atlanta and Houston; and non-metropolitan areas such as Lake Providence, Louisiana; Dexter, Missouri; Sturgis, Michigan; Williamsport, Pennsylvania; Sanford, Maine; Boone, North Carolina; Sheboygan, Wisconsin; Bellingham, Washington; and Tulare, California.

A total of 345 caucasoid subjects between 1 and $3 \mathrm{yr}$ of age were examined by a paedodontist (P.I.) using a mouth mirror and explorer. The examinees were seated in a portable dental chair under a portable dental light. Any child who was unable to support himself in the chair was held on the lap of an adult, usually the mother. An anterior tooth was defined as emerged when $1 \mathrm{~mm}$ of tooth surface was exposed. This was determined subjectively. A posterior tooth was defined as emerged when all four cusp tips were exposed. Nurses used standardized techniques and equipment to weigh and measure height and head circumference of the children. The median number of teeth, mean height, mean weight and median head circumference for each quarter-yr age interval were determined. These data are shown in Tables 1 and 2. Medians were used for the number of teeth and head circumference, because they were found to be better measures of central tendency for the small subject numbers in each quarter-yr age interval. Although 345 subjects were examined, children who had completed the deciduous dentition by approx $2.5 \mathrm{yr}$ were excluded from comparisons of tooth emergence with growth. Only late tooth eruptors, children with less than 20 teeth, could be identified and were included after this age. Thus, a total of 273 children ( 130 boys and 143 girls) remained for comparative analyses between tooth emergence and the measures of growth. Individual children were then rated as above or below the median number of teeth, mean height, mean weight and median head circum-

Table 1. Number of teeth present in CaUCasoid ChILdRen By SEX and aGe, UNITED STATES, 1969-1970

\begin{tabular}{|c|c|c|c|c|c|c|}
\hline \multirow{2}{*}{$\underset{(y r)}{\text { Age range }}$} & \multirow[b]{2}{*}{$\mathbf{N}$} & \multirow{2}{*}{$\begin{array}{c}\text { Mean } \\
\text { age }\end{array}$} & \multirow{2}{*}{$\underset{\text { teeth }}{\text { Mean }}$} & \multicolumn{3}{|c|}{ Percentiles } \\
\hline & & & & 25 th & Median & 75 th \\
\hline $\begin{array}{l}1 \cdot 00-1 \cdot 24 \\
1 \cdot 25-1 \cdot 49 \\
1 \cdot 50-1 \cdot 74 \\
1 \cdot 75-1 \cdot 99 \\
2 \cdot 00-2 \cdot 24 \\
2 \cdot 25-2 \cdot 49 \\
2.50-2.74 \\
2 \cdot 75-2.99\end{array}$ & $\begin{array}{l}18 \\
21 \\
17 \\
17 \\
26 \\
37 \\
14 \\
29\end{array}$ & $\begin{array}{l}1 \cdot 11 \\
1.39 \\
1.61 \\
1.88 \\
2.12 \\
2.35 \\
2.64 \\
2.85\end{array}$ & $\begin{array}{r}7.50 \\
10.52 \\
13.29 \\
15.24 \\
16 \cdot 19 \\
18.40 \\
19.57 \\
19.40\end{array}$ & $\begin{array}{r}5 \\
8 \\
12 \\
14 \\
16 \\
16 \\
20 \\
20\end{array}$ & $\begin{array}{r}7 \\
10 \\
12 \\
16 \\
16 \\
19 \\
20 \\
20\end{array}$ & $\begin{array}{l}8 \\
12 \\
15 \\
16 \\
16 \\
20 \\
20 \\
20\end{array}$ \\
\hline $\begin{array}{l}1 \cdot 00-1 \cdot 24 \\
1.25-1.49 \\
1 \cdot 50-1.74 \\
1 \cdot 75-1.99 \\
2 \cdot 00-2.24 \\
2 \cdot 25-2 \cdot 49 \\
2 \cdot 50-2.74 \\
2 \cdot 75-2.99\end{array}$ & $\begin{array}{l}22 \\
22 \\
21 \\
22 \\
19 \\
18 \\
18 \\
25\end{array}$ & $\begin{array}{l}1.11 \\
1.37 \\
1.61 \\
1.87 \\
2.11 \\
2.39 \\
2.65 \\
2.89\end{array}$ & $\begin{array}{r}6.61 \\
9.09 \\
13.52 \\
15.81 \\
16.90 \\
17.82 \\
19.28 \\
19.66\end{array}$ & $\begin{array}{r}6 \\
8 \\
10 \\
16 \\
16 \\
16 \\
19 \\
20\end{array}$ & $\begin{array}{r}7 \\
8 \\
16 \\
16 \\
16 \\
18 \\
20 \\
20\end{array}$ & $\begin{array}{l}8 \\
11 \\
16 \\
16 \\
18 \\
20 \\
20 \\
20\end{array}$ \\
\hline
\end{tabular}


TABLe 2. MEAN height, Weight AND MEDIAN heAD CIRCUMfERENCE FOR THE CHILDREN, BY SEX AND AGE, UNITED STATES, 1969-1970

\begin{tabular}{|c|c|c|c|c|c|}
\hline $\begin{array}{c}\text { Age range } \\
(\mathrm{yr})\end{array}$ & $\begin{array}{c}\text { Mean } \\
\text { age }\end{array}$ & $N$ & $\begin{array}{l}\text { Mean } \\
\text { height } \\
\text { (cm) }\end{array}$ & $\begin{array}{c}\text { Mean } \\
\text { wejght } \\
(\mathbf{k g})\end{array}$ & $\begin{array}{l}\text { Median head } \\
\text { circumference } \\
\text { (cm) }\end{array}$ \\
\hline $\begin{array}{l}1 \cdot 00-1 \cdot 24 \\
1 \cdot 25-1 \cdot 49 \\
1 \cdot 50-1 \cdot 74 \\
1 \cdot 75-1 \cdot 99 \\
2 \cdot 00-2 \cdot 24 \\
2 \cdot 25-2 \cdot 49 \\
2 \cdot 50-2 \cdot 74 \\
2 \cdot 75-2.99\end{array}$ & $\begin{array}{l}1 \cdot 11 \\
1 \cdot 39 \\
1.61 \\
1.88 \\
2.12 \\
2.35 \\
2.64 \\
2.85\end{array}$ & $\begin{array}{l}18 \\
21 \\
17 \\
17 \\
26 \\
37 \\
14 \\
29\end{array}$ & $\begin{array}{l}76 \cdot 2 \\
78 \cdot 0 \\
82 \cdot 5 \\
84 \cdot 2 \\
87 \cdot 3 \\
88 \cdot 9 \\
89 \cdot 6 \\
91 \cdot 9\end{array}$ & $\begin{array}{l}10.70 \\
10.46 \\
11.77 \\
11.66 \\
12.10 \\
12.63 \\
13 \cdot 43 \\
13.43\end{array}$ & $\begin{array}{l}46 \\
46 \\
47 \\
48 \\
48 \\
48 \\
49 \\
48\end{array}$ \\
\hline $\begin{array}{l}1 \cdot 00-1 \cdot 24 \\
1 \cdot 25-1 \cdot 49 \\
1 \cdot 50-1 \cdot 74 \\
1 \cdot 75-1 \cdot 99 \\
2 \cdot 00-2 \cdot 24 \\
2 \cdot 25-2 \cdot 49 \\
2 \cdot 50-2 \cdot 74 \\
2 \cdot 75-2.99\end{array}$ & $\begin{array}{l}1 \cdot 11 \\
1.37 \\
1.61 \\
1.87 \\
2 \cdot 11 \\
2.39 \\
2.65 \\
2.89\end{array}$ & $\begin{array}{l}22 \\
22 \\
21 \\
22 \\
19 \\
18 \\
18 \\
25\end{array}$ & $\begin{array}{l}77 \cdot 0 \\
80 \cdot 0 \\
82 \cdot 0 \\
85 \cdot 7 \\
88.6 \\
91 \cdot 2 \\
93 \cdot 4 \\
93.9\end{array}$ & $\begin{array}{l}10 \cdot 71 \\
11 \cdot 17 \\
11 \cdot 74 \\
12.42 \\
13 \cdot 13 \\
13 \cdot 47 \\
14 \cdot 78 \\
14 \cdot 58\end{array}$ & $\begin{array}{l}47 \\
48 \\
48 \\
48 \\
49 \\
50 \\
50 \\
50\end{array}$ \\
\hline
\end{tabular}

ference for each age and sex group. The age groups were then pooled to calculate cell values for each two-by-two comparison. To explore associations at the extremes, children in the first and fourth quartiles for the number of teeth present were also compared to the expectancy for each growth parameter by age. Calculations were then made from each two-by-two classification to compute the values in Table 3.

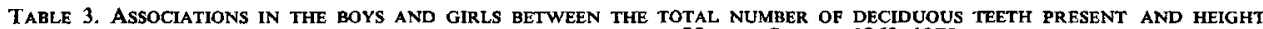
WEIGHT AND HEAD CIRCUMFERENCE, UNITED STATES, 1969-1970

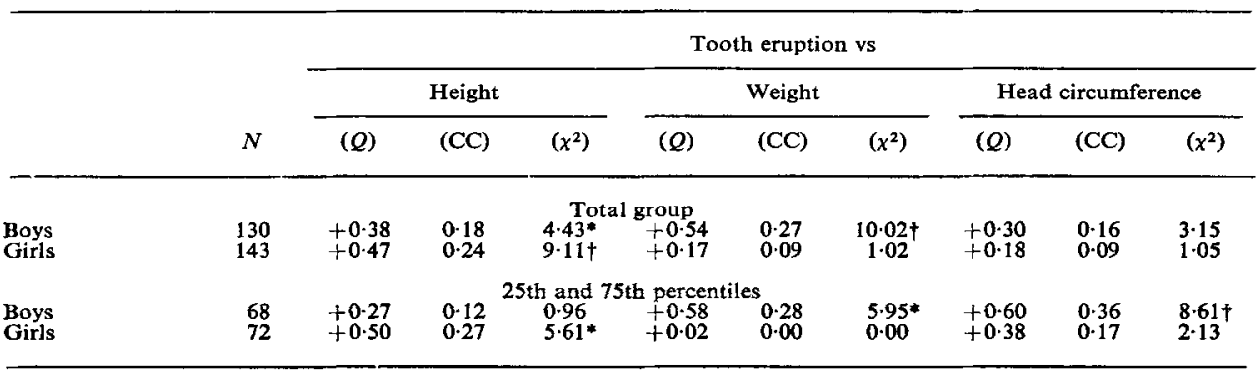

$\chi^{2}$, Chi-square is with one degree of freedom.

$p<0.05$.

CC, Coefficient of contingency.

\section{RESULTS}

As shown in Table 1, the distributions for the number of teeth present at each age are skewed. For this reason conventional means and standard deviations were not used for tooth emergence analysis.

\section{Tooth emergence vs height}

As previous investigators (LYSELL et al., 1962; RoBINOw et al., 1942) concluded that there was no association between tooth emergence and height, the statistic, coefficient of association, $Q$, was used as a simple way to determine the magnitude and direction of any association that may have been present (Yule and Kendall, 1950). The Q's 
between total number of teeth present and height were 0.38 and 0.47 for boys and girls, respectively (Table 3 ). By Chi-square test, there was a significant association in boys $(p<0.05)$ and girls $(p<0.01)$ between the total number of deciduous teeth present and height.

When those subjects above the 75th and those below the 25 th percentiles for tooth emergence were considered in relation to being above or below the median height, the $Q$ for boys decreased considerably, whereas in girls it increased slightly. These findings would indicate that, on the average for a given age, taller or shorter children had more or fewer teeth present, respectively. Because tooth emergence was not linear with age, especially at older ages, a selection of children at the extremes eliminated many children at the ages where tooth emergence and the growth measure had a linear relation. A result of the non-linear relation at the upper extreme, accompanied by a reduction in sample size, reduced the associations for some comparisons when the extremes were considered.

\section{Tooth emergence vs weight}

The associations between tooth emergence and weight are summarized in Table 3. First, there was a strong association for boys, $Q=0.54, \chi^{2}=10.02, p<0.01$, which increased when those below the 25 th and those above the 75 th percentiles were considered. This finding indicates that for a given age, boys, who weigh more or less than the average, had correspondingly more or fewer teeth present. Second, there was no association between tooth emergence and weight in girls.

\section{Tooth emergence vs head circumference}

As shown in Table 3, individuals with advanced or retarded tooth emergence have heads of larger or smaller circumference, respectively, than the average. For girls the association, $Q$, was positive but of low magnitude. When girls above the 75 th or below the 25 th percentiles only were considered, the $Q$ between teeth and head circumference increased. For boys, the association $Q$ was 0.30 when the relation of subjects on each side of the median for tooth emergence and head circumference was considered. Table 3 shows the 75 th and 25 th percentile assessments for tooth emergence in relation to median head circumference was considered. Table 3 shows the 75 th and 25 th percentile assessments for tooth emergence in relation to median head circumference in boys to have been the highest association of all considered, $Q=0.60, x^{2}=8.61$, $p<0.01$. The value for this comparison shows that the extremes in tooth eruption in boys were more closely related to head circumference than to any of the other anthropometric assessments made in this group of children.

\section{DISCUSSION}

This study provides evidence of a positive association between deciduous tooth emergence and height in both boys and girls. Whereas some previous investigators (LySELl et al., 1962; RoBinow et al., 1942) have concluded there was no association, MCGregor, Thompson and BILlewicz (1968) concluded that children with more 
deciduous teeth present for a given age were, on the average, taller than those with fewer teeth present. The findings of the present study appear to be in agreement with those of the latter group of investigators. The degree of association in our study, however, is higher than had been demonstrated previously. It suggests that the total number of deciduous teeth present may be a reflection of general somatic growth. GARN, LEWIS and KEREWSKY (1965) have demonstrated that taller boys and girls are slightly advanced in permanent tooth formation and movement. Gyulavari (1966), LeE, Low and Chang (1965) and Sutow, TerasaKI and KenII (1954) have demonstrated significant positive associations between permanent tooth emergence and skeletal maturation. Therefore, the finding that taller boys and girls were advanced in deciduous tooth emergence was not unexpected.

In our study, there appeared to be an obvious sex difference in the significance of associations between the total number of deciduous teeth present and body weight. For boys, the association was significant but for girls no apparent association between these two variables could be demonstrated. Thus, for boys, tooth emergence had a higher association with weight than height; whereas the opposite was true for girls. This finding of a sex difference in the association between tooth development and weight is similar to a sex difference between these variables seen in early formation of the permanent dentition (GARN et al., 1965).

The most surprising association in these data was that of tooth emergence and head circumference. For boys and girls, the association greatly increased upon comparing only those children who were above the 75th and below the 25 th percentiles for tooth emergence. For all children, head circumference correlated better with weight than with height. As tooth emergence had a greater association with weight for boys than for girls, tooth emergence would be expected to have a greater association with head circumference for boys than for girls.

The above associations between tooth emergence and height could imply that children of greater stature for age may erupt their teeth earlier for genetic reasons. Taller parents would then be expected to have taller children (GARN and RormanN, 1966) advanced in dental emergence. The opposite would then be expected for children of shorter parents. The association between parental stature and deciduous tooth emergence of the offspring, however, has not been tested.

Because height and weight are related to nutritional status, the findings of this study also suggest that deciduous tooth emergence may be an indicator of nutritional status in children during the first $3 \mathrm{yr}$ of life. As children with severe malnutrition are known to have reduced head circumference (WINICK and Rosso, 1969) and brain development (Rosso, Hormazabal and Winick, 1970), the association between the extremes in tooth emergence and head circumference suggests that the timing of deciduous tooth emergence may be an adjunct for identifying children with retarded development as a result of serious nutritional disease. This association, however, will have to be further explored in children who live in an area where nutritional extremes are known to exist.

This study attempted to determine the relation of deciduous tooth emergence to several measures of growth. The results indicate that the timing of deciduous tooth 
emergence is significantly related to child growth and perhaps nutritional status. These findings, however, need to be confirmed for the individual child via longitudinal study.

Acknowledgements-We wish to acknowledge Dr. Stanley M. Garn, Centre for Human Growth and Development, The University of Michigan, for his suggestions and criticisms prior to and during the writing of this paper.

We also wish to thank members of the field team of the national survey for their help in securing the data.

This study was supported by contract MC-R-390050-06-0 from Maternal and Child Health Services, Department of Health, Education and Welfare and by the training grant in oral epidemiology 5T01-DE-00287-05, from the National Institutes of Health.

Résumé-Au cours d'une étude de nutrition, menée en 1969-1970 aux Etats-Unis, les
résultats obtenus chez 273 enfants blancs (âgés de 1-3 ans) sont analysés pour savoir si
l'éruption de la dent temporaire est liée à la taille, au poids et à la circonférence de la tête.
Le coefficient d'association $Q$ est positif pour toutes les comparaisons. Les analyses de
Chi-carrés montrent un rapport significatif entre le nombre total des dents présentes et la
taille, le poids et la circonférence de la tête chez les garçons: les rapports entre dents et
tailles sont significatifs chez les filles. Ces résultats indiquent que le temps d'éruption des
dents temporaires est en rapport significatif avec la croissance somatique générale et
peut-être l'état de nutrition.

Zusammenfassung-Im Verlaufe einer 1969-1970 in den Vereinigten Staaten durchgeführten Ernährungsstudie wurden die bei 273 weißen Kindern im Alter zwischen 1 und 3 Jahren erhobenen Daten analysiert, um festzustellen, ob der Milchzahndurchbruch in Beziehung zu Größe, Gewicht und Kopfumfang steht. Der Assoziationskoeffizient $Q$ war bei allen Vergleichen positiv. Der Chi-Quadrat-Test wies auf signifikante Zusammenhänge zwischen der Gesamtzahl der vorhandenen Zähne und Größe, Gewicht und Kopfumfang bei Jungen hin; bei Mädchen waren diese Zusammenhänge für das Verhältnis Zähne zu Größe signifikant. Diese Ergebnisse zeigen, daß der Zeitpunkt des Milchzahndurchbruches in unmittelbarer Beziehung zum allgemeinen somatischen Wachstum und vielleicht auch zum Ernährungszustand steht.

\section{REFERENCES}

BOAS, F. 1927. The eruption of deciduous teeth among Hebrew infants. J. dent. Res. 7, 245-253.

FALKNER, F. 1957. Deciduous tooth eruption. Archs Dis. Child. 32, 386-391.

Frrguson, A., Scott, R. B. and Bakwin, H. 1957. Growth and development of Negro infants. VIII. Comparison of the deciduous dentition in negro and white infants. J. Pediat. 50, 327-331.

Garn, S. M., Lewis, A. B. and KerewSKY, R. S. 1965. Genetic, nutritional, and maturational correlates of dental development. $J$. dent. Res. 44, 228-242.

GARN, S. M., and RoHmanN, C. G. 1966. Interaction of nutrition and genetics in the timing of growth and development. Pediat. Clin. N. Am. 13, 353-379.

Gyulavari, O. 1966. Dental and skeletal development of children with low birth weight. Acta Paediat. Acad. Scient. Hung. 7, 301-310.

KISH, L. and HESS, I. 1965. The survey research centre's national sample for dwellings. Institute for Social Research Pub. No. 2315, The University of Michigan, Ann Arbor, Michigan.

LeE, M. M. C., Low, W. D. and ChANG, K. S. F. 1965. Relationship between dental and skeletal maturation in Chinese children. Archs oral Biol. 10, 883-891.

Lysell, L., Magnusson, B. and Thilander, B. 1962. Time and order of eruption of the primary teeth. Odont. Revy 13, 217-234.

MAY, E. W., and WYGANT, T. M. 1939. Rachitic studies. II. The value of irradiated evaporated milk in the prevention of rickets in premature, weakling, and normal full term infants. Archs Pediat. 56, 356-374. 
MCGregor, I. A., Thompson, A. M. and Billewicz, W. Z. 1968. The development of primary teeth in children from a group of Gambian villages and critical examination of its use for estimating age. Br. J. Nutr. 22, 307-314.

Meredirh, H. V. 1946. Order and age of eruption for the deciduous dentition. J. dent. Res. 25, 43-66.

Robinow, M., Richards, J. W. and ANDERson, M. 1942. The eruption of deciduous teeth. Growth, 42, 127-133.

Rosso, P., Hormazabal, J., and Winick, M. 1970. Changes in brain weight, cholesterol, phospholipid, and dna content in marasmic children. Am. J. clin. Nutr. 23, 1275-1279.

SANDLER, H. C. 1944. The eruption of deciduous teeth. J. Pediat. 25, 140-147.

Sutow, W. W., Terasaki, T. and KenJI, O. 1954. Comparison of skeletal maturation with dental status in Japanese children. Pediatrics 14, 327-333.

WeDGWOOD, M. and Holt, K. S. 1968. A longitudinal study of the dental and physical development of 2-3-year-old children who were underweight at birth. Biol. Neonat. 12, 214-232.

WinICK, M., and Rosso, P. 1969. Head circumference and cellular growth of the brain in normal and marasmic children. J. Pediat. 74, 774-778.

Yule, G. U., and Kendall, M. G. 1950. An Introduction to the Theory of Statistics, 14th edn, p. 30. Hafner, New York. 